\title{
Angiotensin II, a neuropeptide at the frontier between endocrinology and neuroscience: is there a link between the angiotensin II type 2 receptor and Alzheimer's disease?
}

\section{Nicole Gallo-Payet ${ }^{*}$, Marie-Odile Guimond' ${ }^{1}$ Lyne Bilodeau', Charlotta Wallinder ${ }^{2}$, Mathias Alterman ${ }^{2}$ and Anders Hallberg ${ }^{2}$}

\author{
Service of Endocrinology, Department of Medicine, Faculty of Medicine, Centre de recherche clinique Etienne-Le Bel du Centre hospitalier universitaire de \\ Sherbrooke, Université de Sherbrooke, Sherbrooke, QC, Canada \\ Department of Medicinal Chemistry, Biomedicinska Centrum, Uppsala University, Uppsala, Sweden
}

\section{Edited by:}

Billy K. C. Chow, University of Hong

Kong, China

Reviewed by:

Ying-Shing Chan, University of Hong Kong, China

Nicolas Vitale, Centre National de la Recherche Scientifique, France

\section{*Correspondence:}

Nicole Gallo-Payet, Service

d'Endocrinologie, Département de

Médecine, Faculté de Médecine et des Sciences de la Santé, Université de Sherbrooke, 3001, 12e Avenue

Nord, Sherbrooke, QC, Canada J1H $5 \mathrm{~N} 4$

e-mail:nicole.gallo-payet@ usherbrooke.ca
Amyloid- $\beta$ peptide deposition, abnormal hyperphosphorylation of tau, as well as inflammation and vascular damage, are associated with the development of Alzheimer's disease (AD). Angiotensin II (Ang II) is a peripheral hormone, as well as a neuropeptide, which binds two major receptors, namely the Ang II type 1 receptor (AT1R) and the type 2 receptor (AT2R). Activation of the AT2R counteracts most of the AT1R-mediated actions, promoting vasodilation, decreasing the expression of pro-inflammatory cytokines, both in the brain and in the cardiovascular system. There is evidence that treatment with AT1R blockers (ARBs) attenuates learning and memory deficits. Studies suggest that the therapeutic effects of ARBs may reflect this unopposed activation of the AT2R in addition to the inhibition of the AT1R. Within the context of $A D$, modulation of $A T 2 R$ signaling could improve cognitive performance not only through its action on blood flow/brain microcirculation but also through more specific effects on neurons. This review summarizes the current state of knowledge and potential therapeutic relevance of central actions of this enigmatic receptor. In particular, we highlight the possibility that selective AT2R activation by non-peptide and highly selective agonists, acting on neuronal plasticity, could represent new pharmacological tools that may help improve impaired cognitive performance in $A D$ and other neurological cognitive disorders.

Keywords: angiotensin II, angiotensin type 2 receptor, neuron, cognition, brain damage, vasodilation, Alzheimer's disease

\section{INTRODUCTION}

Angiotensin II (Ang II) is the active end-product of the reninangiotensin system (RAS). In the classical view, Ang II is produced from angiotensinogen through a series of proteolytic cleavage events, conducted successively by renin, followed by angiotensinconverting enzyme (for review see de Gasparo et al., 2000; de Kloet et al., 2010). However, in addition to this classical RAS, several alternative pathways have been identified, for which description is out of the scope of this review, but recently reviewed by de Kloet et al. (2010) and Abassi et al. (2009). Ang II is a peripheral hormone, as well as a neuropeptide, which plays a major role in the central regulation of blood pressure and in the stress response. Indeed, since the pioneer studies of Mendelsohn et al. (1988) and Unger et al. (1988), the existence of a RAS in the brain is now well established. The various components (angiotensinogen, renin, angiotensin-converting enzyme, Ang II, and Ang II receptors) are found in areas of the brain involved in the regulation of fluid and electrolyte balance, in the regulation of arterial pressure and in structures involved in cognition, behavior, and locomotion (for review see Phillips and de Oliveira, 2008; Horiuchi et al., 2010).

Angiotensin II binds two major receptors: the Ang II type 1 receptor (AT1R) and the type 2 receptor (AT2R). Since Ang II modulates blood pressure and the stress response by binding the
AT1R, AT1R blockers (ARBs) have been widely used as antihypertensive drugs. There is also evidence that ARB treatment attenuates learning and memory deficits, increases cerebral blood flow, and helps protect against brain ischemia and inflammation (Li et al., 2005; Zhou et al., 2006; Phillips and de Oliveira, 2008; Mogi and Horiuchi, 2009; Sakata et al., 2009; Horiuchi et al., 2010). In the presence of ARBs, which selectively block the AT1R, Ang II binds to the less-abundant AT2R. Several studies suggest that the therapeutic effects of ARBs may reflect this unopposed activation of the AT2R as well as the inhibition of the AT1R (Li et al., 2007b; Tsukuda et al., 2007, 2009; Arganaraz et al., 2008; Gao et al., 2008; McCarthy et al., 2009).

Within the context of Alzheimer's disease (AD), modulation of AT2R signaling could improve cognitive performance not only through its action on blood flow/brain microcirculation but also through more specific effects on neurons. This review summarizes the current state of knowledge and potential therapeutic relevance of central actions of this enigmatic receptor.

\section{EXPRESSION AND ROLES OF THE AT2R IN THE BRAIN}

One of the most striking features of the AT2R is its high level of expression in most fetal tissues, including the brain, and the dramatic increase in the AT1/AT2 receptor ratio after birth 
(Millan et al., 1991; Tsutsumi and Saavedra, 1991). This pattern of expression strongly implicates the AT2R in fetal development. In the adult, the AT2R is predominantly expressed in the locus coeruleus, ventral and dorsal parts of lateral septum, superior colliculus and subthalamic nucleus, many nuclei of the thalamus, and nuclei of the inferior olive. The cingulate cortex, the molecular layer of the cerebellar cortex, the superior colliculus and paraventricular nuclei contain both AT1 and AT2 receptors (Millan et al., 1991; Tsutsumi and Saavedra, 1991; Lenkei et al., 1996, 1997). More recent studies have also identified AT2R RNA and protein in the substantia nigra pars compacta (Grammatopoulos et al., 2007) and in the hippocampus (Arganaraz et al., 2008; Abdalla et al., 2009). Thus, in the adult, the AT2R are concentrated in areas involved in control and learning of motor activity, sensory areas, and selected limbic system structures. At the cellular level, the AT2R is localized in neurons but not in astrocytes (Bottari et al., 1992; Lenkei et al., 1996; Gendron et al., 2003b). It is well-accepted that AT2R stimulation counteracts most AT1R-mediated actions, promoting vasodilation, inhibiting growth, decreasing the expression of pro-inflammatory cytokines, and increasing expression of anti-inflammatory cytokines, both in the brain and in the cardiovascular system (for reviews see Gendron et al., 2003b; Mogi et al., 2007a, 2008; Arganaraz et al., 2008; Mogi and Horiuchi, 2009; Porrello et al., 2009; Sakata et al., 2009; Tsukuda et al., 2009; Figure 1).

\section{IS THERE A LINK BETWEEN AT2R ACTIVATION AND AD?}

Amyloid- $\beta$ (A $\beta$ ) peptide deposition in senile plaques and the presence of neurofibrillary tangles (NFTs) are the main pathological hallmarks of AD. However, other structural and functional alterations, including inflammation, increased oxidative stress, and vascular damage/ischemia, are also associated with $\mathrm{AD}$; these alterations may contribute to neuronal and synaptic dysfunction and loss as well as the ensuing cognitive deficits and dementia of this disorder (Iadecola, 2004; Zlokovic, 2005; LaFerla et al., 2007; Boissonneault et al., 2009; Mucke, 2009; Nelson et al., 2009). In addition, since the development of the amyloid hypothesis of Hardy and Selkoe (2002), evidence strongly suggests that soluble oligomers of $A \beta$ may cause early cognitive impairment, even in the absence of overt cell death (review in Mucke et al., 2000; Hardy and Selkoe, 2002; Lesne et al., 2006; Haass and Selkoe, 2007; Selkoe, 2008; Wray and Noble, 2009).

The abnormal hyperphosphorylation and altered conformation of the microtubule-associated protein (MAP) tau precedes its assembly into paired helical filaments and its accumulation in NFTs (Buee et al., 2000; Andorfer et al., 2003; Gallo et al., 2007; Hanger et al., 2009; Iqbal et al., 2009). Tau is a substrate for several protein kinases, such as glycogen synthase kinase-3 (GSK-3) and cyclin-dependent kinase (cdk5), and for phosphatases such as protein phosphatase-2A (PP2A); PP2A activity is down-regulated in the AD brain (Buee et al., 2000; Andorfer et al., 2003; Gallo et al., 2007; Hernandez and Avila, 2008; Hanger et al., 2009; Iqbal et al., 2009; Hernández et al., 2010).

Moreover, experimental evidence suggests that cerebral perfusion is decreased in $\mathrm{AD}$ (Farkas and Luiten, 2001; de la Torre, 2004; Zlokovic, 2008; Liu et al., 2009). Indeed, the structural and functional integrity of the brain depends on the delicate balance between substrate delivery through blood flow and energy demands imposed by neural activity. Neurons, astrocytes and vascular cells seemingly constitute a functional unit, the primary purpose of which is to maintain the homeostasis of the brain's microenvironment. Alterations of these vascular regulatory mechanisms lead to brain dysfunction and disease. The emerging view is that cerebrovascular dysregulation is a feature not only of

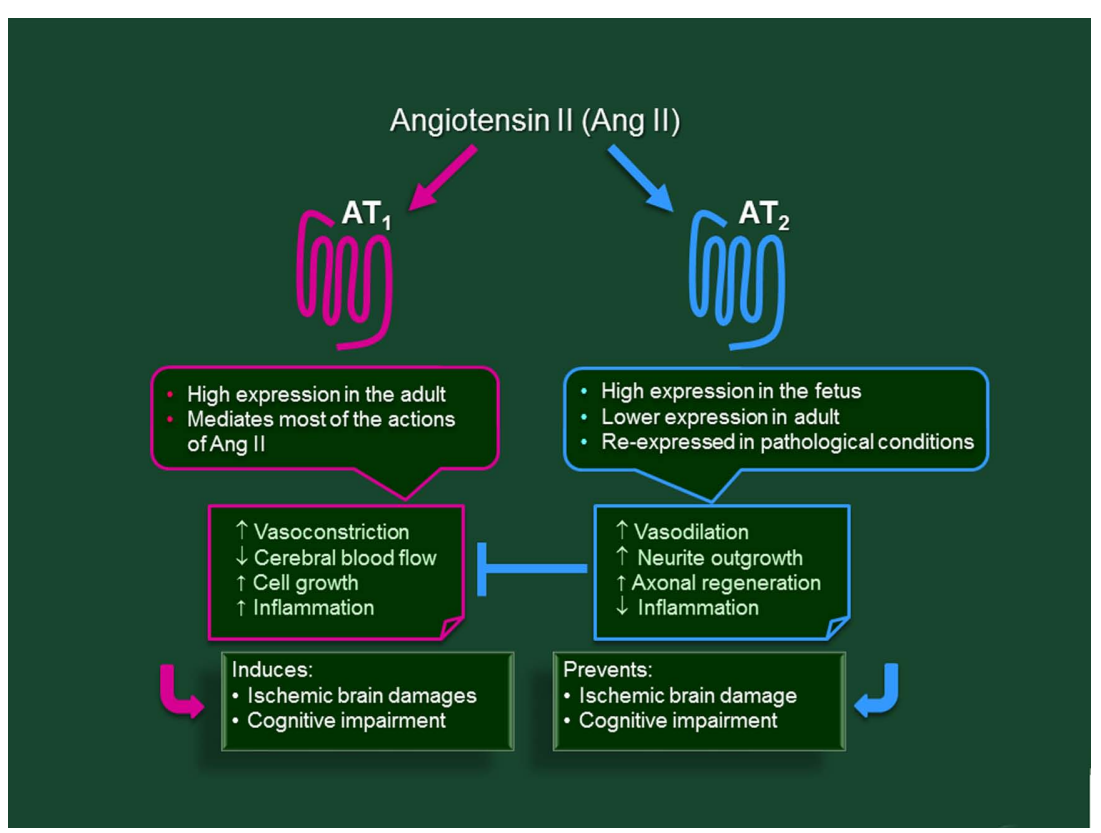

FIGURE 1 | Summary of the properties and main effects targeted by AT1 and AT2 receptors of angiotensin II in the brain. 
cerebrovascular pathologies such as stroke, but also of neurodegenerative conditions such as AD (Iadecola et al., 2009). Since studies suggest that $\mathrm{A} \beta$ has deleterious actions both on neurons and cerebral blood vessels, the neuronal and vascular actions of this peptide may act synergistically to induce brain dysfunction in AD (Iadecola, 2004; Zlokovic, 2005).

Recent studies have revealed that aging, hypertension, and $\mathrm{AD}$ trigger common signaling pathways that lead to deleterious effects on the regulation of the cerebral circulation. These findings reinforce the notion that cerebrovascular dysfunction plays a key role in the cognitive impairment associated with these conditions (Iadecola et al., 2009). In the entire trademark dysfunctions associated with $\mathrm{AD}$ mentioned above, there is several indirect lines of evidence suggesting that AT2 receptor activation may have a beneficial effect (de la Torre, 2004).

All of the components of the RAS are found in the brain, where they actively modulate functions such as stress (Saavedra et al., 2005; Saavedra and Benicky, 2007), exploratory behavior, anxiety, learning, and memory acquisition (Wright et al., 2002; Phillips and de Oliveira, 2008). Both the AT1R and the AT2R have been detected in brain areas responsible for these functions, including the amygdala, hippocampus, lateral septum, and frontal cortex (Song et al., 1991, 1992; Lenkei et al., 1996; Phillips and Sumners, 1998; Arganaraz et al., 2008; Abdalla et al., 2009). The initial studies indicating a role of AT2R in cognitive improvement arise from observations in AT2R-deficient mice. The targeted disruption of the Agtr2 gene (which codes for the AT2R) resulted not only in a significant increase in blood pressure, but also in attenuated exploratory behavior and impaired performance in a spatial memory task (Hein et al., 1995; Ichiki et al., 1995; Okuyama et al., 1999; Maul et al., 2008). Several recent studies have indicated a beneficial role for ARBs in the cognitive impairment associated with vascular diseases, $\mathrm{AD}$, and other neurodegenerative diseases (Phillips and de Oliveira, 2008; Fujita et al., 2009; Mogi and Horiuchi, 2009). For instance, treatment with the ARB valsartan attenuates oligomerization of $A \beta$ peptides into high molecular weight oligomeric peptides and reduces cognitive deterioration in Tg2576 mice, a model of AD-type neuropathology that expresses a pathogenic mutant of the amyloid precursor protein (APP; Wang et al., 2007). On the other hand, other studies with the same model (Tg2576 mice) have shown that $A \beta$ induces the formation of cross-linked AT2R oligomers in the hippocampus that disrupt Ang II signaling. This $A \beta$-induced AT2R oligomerization was associated with enhanced neurodegeneration. Conversely, stereotactic inhibition of AT2R oligomers by RNA interference delayed tau phosphorylation in Tg2576 (Abdalla et al., 2009).

Numerous studies suggest that the beneficial cellular effects of the AT2R result in improved physiological parameters relevant to AD patients:

- Ang II type 2 receptor activation promotes vasodilation and the anti-inflammatory process - Considerable evidence suggests that AT1R blockade and increased AT2R stimulation improve cerebral blood flow, thereby helping to protect against brain ischemia and inflammation (Iwai et al., 2004; Li et al., 2005; Zhou et al., 2006; Sakata et al., 2009), and, moreover, that
AT2R activation improves the microcirculation (for reviews, see Phillips and de Oliveira, 2008; Horiuchi et al., 2010).

- Ang II type 2 receptor activation protects against brain damage - Numerous recent studies conducted in rodents treated with ARBs suggest that AT2R protects against cerebral ischemiainduced neuronal injury (Grammatopoulos et al., 2004; Li et al., 2005; Tsukuda et al., 2007, 2009; McCarthy et al., 2009), and altered dendritic and neuronal spine morphology (Maul et al., 2008; for review see Mogi and Horiuchi, 2009). Confirming these observations, it has been reported that AT2R stimulation supports neuronal survival and neurite outgrowth in response to ischemia-induced neuronal injury (Li et al., 2005; Sakata et al., 2009). Further supporting a role of AT2R in neurite outgrowth are observations from models of nerve injury which have elegantly shown that the AT2R has regenerative capabilities associated with restored behavioral function and anatomic innervation after sciatic nerve crush and optical axotomy (Gallinat et al., 1998; Lucius et al., 1998; Reinecke et al., 2003; Li et al., 2005).

- Alzheimer's disease and the neurotrophic hypothesis: a role for AT2R? -As recently summarized by Schindowski et al. (2008), neurotrophic factors [such as nerve growth factor (NGF) and brain-derived neurotrophic factor] are key regulators not only for development, maintenance and survival but also for cognition and storage of memory. They activate various cell signaling pathways acting through the tropomyosin-related kinase or tyrosine receptor kinase family (Trk). Most neurodegenerative dementias are linked to failures in axonal transport of neurotrophic factors from the cell body (where they are synthesized) to their sites of action. For example, in the absence of NGF, morphology and functions of cholinergic neurons are impaired, resulting in a decrease in cholinergic transmission. In this context, we have shown that AT2R-mediated effects in vitro are modulated by the presence of growth factors in the culture medium, and are mediated by growth factor-related signaling pathways. In particular, the signaling mechanisms leading to neurite outgrowth in NG108-15 cells involves the TrkA-mediated activation of Rap1/B-Raf, which in turn, activates MEK to induce a delayed but sustained activation of p42/p44 mapk (Gendron et al., 2003a; Plouffe et al., 2006).

- Alzheimer's disease as a consequence of hypertension and metabolic syndrome: a role for AT2R? - Several recent studies indicate that ARBs may protect against the cognitive impairments associated with vascular disease, $\mathrm{AD}$, and other neurodegenerative diseases (Mogi and Horiuchi, 2009). For example, pretreatment with a non-hypotensive dose of telmisartan significantly inhibits the cognitive decline induced by intracerebroventricular (i.c.v.) injection of A $\beta 1-40$, an experimental model of AD (Tsukuda et al., 2007, 2009; Mogi et al., 2008), and also prevents A $\beta$ deposition in AD models (Mogi et al., 2006, 2007b, 2008; Tsukuda et al., 2007, 2009). However, the link between AT2R and cognitive defects is not yet clearly established. Figure 2 provides a general overview of the functional changes of $\mathrm{AD}$ and how AT2R could help recover some of these changes.

- Type 2 diabetes mellitus (T2DM), hypertension and metabolic syndrome (which is defined as a cluster of obesity, high blood pressure, hyperglycemia, and insulin resistance) are associated 


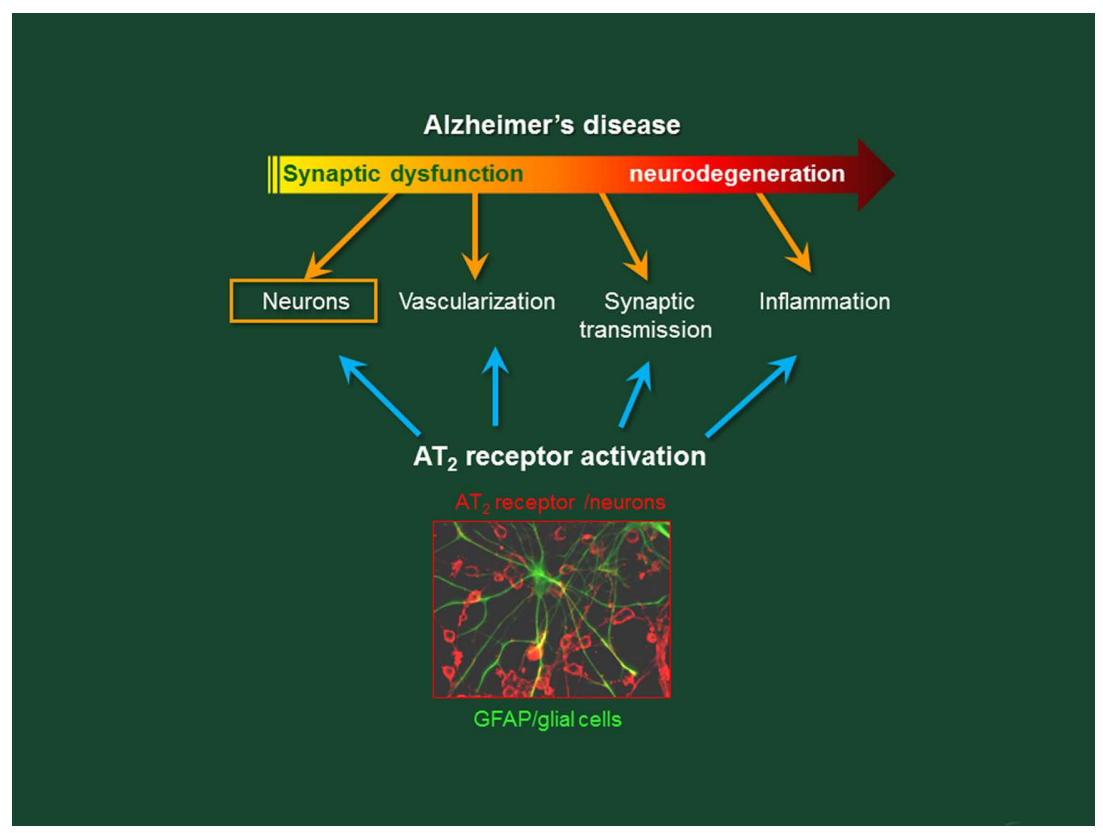

FIGURE 2 | Alzheimer's disease: targets of functional disruptions and proposed protective functions associated with the activation of the AT2 receptor of angiotensin II.

with an increased risk of dementia (both $\mathrm{AD}$ and vascular dementia) (Yaffe et al., 2004a,b; Biessels and Kappelle, 2005; Qiu et al., 2005; Whitmer et al., 2005; Craft, 2006, 2009; Mogi et al., 2006; de la Monte, 2009; Mogi and Horiuchi, 2009). In T2DM patients, a major clinical study (Study on Cognition and Prognosis in the Elderly, SCOPE; Lithell et al., 2003) and a clinical double-blind study (Tedesco et al., 1999) have indicated that ARBs have a further therapeutic effect on impaired cognitive function beyond their antihypertensive effects compared with other antihypertensive drugs. In this context, Tsukuda et al. have demonstrated that candesartan improves the impaired cognitive function induced by T2DM, with multiple beneficial effects (Tsukuda et al., 2007; Mogi et al., 2008).

\section{LINKING SIGNALING AND FUNCTION: ALWAYS A DIFFICULT CHALLENGE!}

During the past 5 years, significant progress has been achieved in elucidating some of the puzzling elements of the AT2R-signaling pathway proteins (Gendron et al., 2003a; Mogi and Horiuchi, 2009; Porrello et al., 2009; Steckelings et al., 2010a; Figure 3). Some of these elements may be linked to improvement of impaired signaling functions as observed in $\mathrm{AD}$ :

- Ang II type 2 receptor may improve synaptic plasticity through effects on ionic channel activity, since AT2R activation decreases T-type calcium channel activity, increases $\mathrm{K}^{+}$channel activity (Kang et al., 1992, 1993; Buisson et al., 1995), and alters actin cytoskeleton dynamics (Kilian et al., 2008).

- Ang II type 2 receptor activation may support microtubule organization and dynamics. Indeed, several studies have reported that AT2R activates PP2A phosphatase (Huang et al., 1995, 1996a,2008; Kilian et al., 2008). PP2A is markedly deficient in $\mathrm{AD}$, and responsible for a sustained increase in ERK1/ERK2, one of the kinases involved in glycogen synthase kinase-3 (GSK-3) inactivation. We have also shown that activity of Fyn, a srcfamily kinase member, is required for AT2R-induced neurite outgrowth (Guimond et al., 2010a). Since tau is a substrate for both PP2A phosphatases, GSK-3 and Fyn, AT2R activation may control the equilibrium between tau phosphorylation and dephosphorylation (Hernandez and Avila, 2008; Hanger et al., 2009; Hernández et al., 2010).

- Ang II type 2 receptor may also improve neurite architecture, through effects on MAPs, as shown in neuronal cell lines (Laflamme et al., 1996; Meffert et al., 1996; Côté et al., 1999; Li et al., 2007a).

- Through methyl methanesulfonate sensitive 2 (MMS2; Mogi et al., 2007a) and peroxisome proliferator-activated receptor (PPAR $\gamma$; Mogi et al., 2008), the AT2R improves cognitive function and the decrease in hippocampal neurogenesis observed in amyloid- $\beta$-injection-induced cognitive decline (Mogi et al., 2008) or in AT2R-deficient mice (Mogi et al., 2007a; for review, see Mogi and Horiuchi, 2009; Horiuchi et al., 2010).

- Ang II type 2 receptor activation may counteract vasoconstriction, and favor vasodilation/vasorelaxation, through an increase in nitric oxide (NO)-cGMP production and a decrease in superoxide production, NADPH oxidase superoxide production, and NADPH oxidase (reviewed in Volpe et al., 2003; Widdop et al., 2003; Steckelings et al., 2005).

- Ang II type 2 receptor activation by CGP42112 increases neuronal survival and minimizes experimental post-stroke injury (McCarthy et al., 2009), indicating that centrally administered CGP42112 exhibits a neuroprotective effect. Such protective 


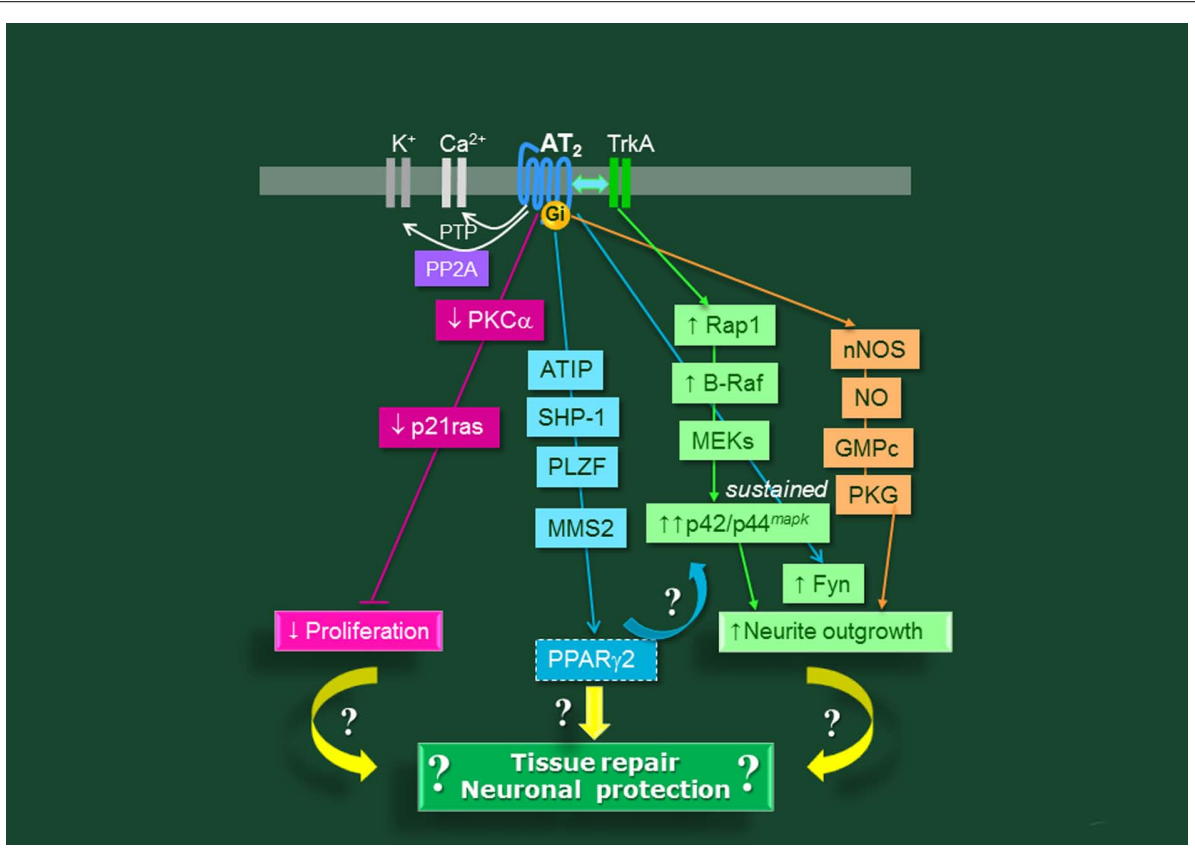

FIGURE 3 | Main signaling pathways for the AT2 receptor of angiotensin II in the brain.

effects may be consecutive to an increase in nitric oxide (NO)cGMP production and a decrease in superoxide production and NADPH oxidase superoxide production and NADPH oxidase (de la Torre, 2004; Iadecola et al., 2009) or to decreased inflammation. Indeed, AT2R attenuates chemical hypoxia-induced caspase-3 activation in primary cortical neuronal cultures (Grammatopoulos et al., 2004). As recently reviewed (Rompe et al., 2010; Stegbauer and Coffman, 2011), AT2R activation, as in other inflammatory models, may decrease tumor necrosis factor-alpha (TNF- $\alpha$ ) and NF-kB (nuclear factor kappalight-chain-enhancer of activated B cells) activity, resulting in decreased production of interleukin 6 (IL-6). This effect is initiated through increased activation of protein phosphatases and increased synthesis of epoxyeicosatrienoic acid (Rompe et al., 2010).

Nevertheless, certain contradictory studies suggest that AT2R expression and conformation may change with age and may be associated with some of the deleterious changes in AD (Kerr et al., 2005; Abdalla et al., 2009). These conflicting hypotheses have been difficult to reconcile because of experimental limitations, particularly the lack of an orally active, selective ligand for the AT2R, as discussed in the next section. Moreover, the earliest events associated with activation of AT2R and the contribution of AT2R signaling to cognitive decline remains unclear.

Other advances in the field of AT2R signaling include the identification of direct intracellular partners, including the phosphatase SHP-1 (Cui et al., 2001; Feng et al., 2002; Nouet et al., 2004; Mogi et al., 2006; Li et al., 2007b), the transcription factor promyelocytic zinc finger protein, PLZF (Senbonmatsu et al., 2003) and the AT2 receptor-interacting protein (ATIP), also called AT2R binding protein of $50 \mathrm{kDa}$ (ATBP50; Nouet et al., 2004; Wruck et al.,
2005; reviewed in Mogi et al., 2007a; Funke-Kaiser et al., 2010; Rodrigues-Ferreira and Nahmias, 2010; see Figure 3 for a synopsis). Moreover, recent studies have identified intracellular crosstalk pathways between the AT1R and the AT2R at the gene expression level. Indeed, AT1R activation enhances AT2R mRNA degradation, but AT2R activation increases AT2R mRNA transcription (Shibata et al., 1997).

\section{THE AT2R: PREVIOUS LIMITATIONS AND NEW PERSPECTIVES}

As previously mentioned, the identification of AT2R-specific actions has been hampered by the absence of appropriate selective ligands. Until recently, CGP42112A was the only AT2R agonist available, but it also acted as an antagonist at high concentrations (Dubey et al., 1998; Martineau et al., 1999; Ruiz-Ortega et al., 2000; Fabiani et al., 2001). Furthermore, due to its peptidic nature, CGP42112A could not be used readily in in vivo studies. Anders Hallberg and colleagues, as recently summarized by Steckelings et al. (2010a,b) and Unger and Dahlof (2010), have characterized the properties of several non-peptidic compounds derived from the prototype non-selective AT1/AT2 receptor agonist L-162,313 (Wan et al., 2004; Georgsson et al., 2005, 2006; Rosenstrom et al., 2005; Wu et al., 2006; Murugaiah et al., 2007). One of these ligands, the M24 compound (originally called C21; Wan et al., 2004; Georgsson et al., 2007), exhibits high affinity for the AT2R (0.4 nM), but very low affinity for the AT1R (>10,000 nM) and acts as an AT2R agonist (Wan et al., 2004). Using a neuronal/glioma cell line (a variant of NG108-15 cells expressing only the AT2R), we found that C21/M24 stimulates neurite outgrowth through sustained activation of $\mathrm{p} 42 / \mathrm{p} 44^{\mathrm{mapk}}$, as observed with Ang II or CGP42112A (Wan et al., 2004). In addition, C21/M24 also decreases cell proliferation in NG108-15 cells, as does CGP42112A. In addition to our results, 
others have found that C21/M24 lowered mean arterial blood pressure in hypertensive rats (Wan et al., 2004; Gelosa et al., 2009; Bosnyak et al., 2010), improved ventricular function in a model of rat myocardial infarction (Kaschina et al., 2009), and corrected several intracellular perturbations and pro-inflammatory conditions (Kaschina et al., 2009; Rompe et al., 2010). Thus, C21/M24 is the most selective AT2R agonist available to date and represents a unique tool to delineate the specific roles of AT2R in different cellular and animal models (Steckelings et al., 2010a; Unger and Dahlof, 2010; recently reviewed in Steckelings et al., 2010b).

The next challenge is now to verify whether AT2R activation by C21/M24 could rescue or improve cognitive performance. To answer this question, we have induced learning deficiency by a 2 -week treatment with intracerebral injection of amyloid- $\beta(A \beta)$. Key findings from our preliminary experiments are that selective AT2R activation by C21/M24 attenuates the learning disturbance in the Y-maze and water-maze tasks more efficiently than AT1R blockade by losartan (Guimond et al., 2010b and unpublished results). It is indeed well documented that $A \beta$ treatment significantly induces a significant learning disturbance in the Y-maze and water-maze tasks, in addition to resulting in moderate neuronal loss and promoting amyloid deposition in the cortex and hippocampus (Yamaguchi and Kawashima, 2001; Tajima et al., 2005; Mogi et al., 2006, 2008; Liu et al., 2009; Klyubin et al., 2011; Srivareerat et al., 2011).

From the previous results demonstrating that AT2R stimulation modulates phosphorylation of MAPs, including MAP2 and MAP1B or tau, as well as modulates interactions between MAPs and microtubules (Laflamme et al., 1996; Meffert et al., 1996; Côté et al., 1999; Li et al., 2007b), it appears therefore that elucidating the signaling mechanisms linking AT2R activation and cytoskeletal remodeling is key to understanding the cognitive roles of the AT2R in hippocampal neurons.

Based on the current paradigms of AT1R/AT2R function, one aspect of AT1R/AT2R regulation is particularly intriguing. Could the age-related shift in the relative expression of the AT1R and AT2R, in which AT1R expression increases and AT2R expression decreases, explain some cellular aspects of aging, especially those relating to altered cell number (von Bohlen und Halbach et al., 2001)?

\section{CONCLUSION - RELEVANCE TO ALZHEIMER'S DISEASE AND RELATED DEMENTIAS}

Poor cognitive performance in $\mathrm{AD}$ significantly impairs social interaction and the quality of life of patients. Therefore any treatment aimed at improving cognitive functions is likely to slow down symptoms and improve quality of life. An estimated 33 million

\section{REFERENCES}

Abassi, Z., Winaver, J., and Feuerstein, G. Z. (2009). The biochemical pharmacology of renin inhibitors: implications for translational medicine in hypertension, diabetic nephropathy and heart failure: expectations and reality. Biochem. Pharmacol. 78, 933-940.

Abdalla, S., Lother, H., El Missiry, A., Langer, A., Sergeev, P., El

elderly persons worldwide suffer from dementia, and this number is expected to reach 81.1 million by 2040 (Ferri et al., 2005; Source: Rising Tide: the Impact of Dementia on Canadian Society, a report of the Alzheimer's Society of Canada). Life style-related disorders, such as hypertension, diabetes mellitus, and obesity have moreover been implicated as risk factors for dementia (Yaffe et al., 2004a,b; Biessels and Kappelle, 2005; Qiu et al., 2005; Whitmer et al., 2005; Craft, 2006, 2009; Mogi et al., 2006; de la Monte, 2009; Mogi and Horiuchi, 2009).

As described in the previous sections, AT2R activation may act at several locations in the cascade of alterations leading to cognitive impairment and neuronal dysfunction observed in $\mathrm{AD}$. In particular, AT2R may act not only at the neuronal level, but also on vasculature and on inflammation associated with Alzheimer's. As outlined in this review, an increasing number of studies suggest that the protective effects of angiotensin II (AT1) receptor blockers on brain damage and cognition may result not only from the inhibition of AT1R effects, but also from the beneficial effect due to unopposed activation of AT2R. In addition, the relationship between impaired energy metabolism/obesity/insulin resistance and the increased risk of dementia (both $\mathrm{AD}$ and vascular dementia; Yaffe et al., 2004a,b; Qiu et al., 2005; Whitmer et al., 2005; Mogi and Horiuchi, 2009) emphasizes that all the mechanisms by which AT2R acts may have a beneficial protective effect. If further research confirms the promising early results, the neuroprotective effect of central AT2R stimulation with the recently developed C21/M24, a non-peptide, selective AT2R agonist, may thus represent a new pharmacological tool in $\mathrm{AD}$ and others neurological cognitive disorders. In addition, unraveling the underlying effects of the AT2R on neuronal plasticity may lead to the development of even more selective therapies.

\section{ACKNOWLEDGMENTS}

The authors wish to deeply thank Lucie Chouinard, Lucie Boufardand Sandra Pinard (technicians), and Drs Louis Gendron (University of Sherbrooke), Thomas Stroh (Montreal Neurological Institute, McGill University), Jean-Marc Gallo and Wendy Noble (Centre for Neurodegeneration Research, King's College, London, United Kingdom) for their contributions and stimulating discussions. We sincerely thank Dr. Kerry Hull (Department of Biology, Bishops's University) for critical review of the manuscript. This work was supported by grants from the Alzheimer's Society of Canada to Nicole Gallo-Payet, Louis Gendron, and Thomas Stroh and by the program of Canada Research Chair to Nicole GalloPayet. Nicole Gallo-Payet is a past holder of the Canada Research Chair in Endocrinology of the Adrenal Gland.

mice expressing normal human tau isoforms. J. Neurochem. 86, 582-590.

Arganaraz, G. A., Konno, A. C., Perosa, S. R., Santiago, J. F., Boim, M. A., Vidotti, D. B., Varella, P. P., Costa, L. G., Canzianm, M., Porcionatto, E. M., Yacubian, A. C., Sakamoto, H., Carrete, H. Jr., Centeno, R. S., Amado, D., Cavalheiro, J. A. Jr., and Mazzacoratti Mda, G. (2008). The renin-angiotensin system is upregulated in the cortex and hippocampus of patients with temporal lobe epilepsy related to mesial temporal sclerosis. Epilepsia 49, 1348-1357.

Biessels, G. J., and Kappelle, L. J. (2005). Increased risk of Alzheimer's disease in type II diabetes: insulin resistance of the brain or insulin-induced amyloid pathology? Biochem. Soc. Trans. 33, 1041-1044. 
Boissonneault, V., Filali, M., Lessard, M., Relton, J., Wong, G., and Rivest, S. (2009). Powerful beneficial effects of macrophage colony-stimulating factor on beta-amyloid deposition and cognitive impairment in Alzheimer's disease. Brain 132, 1078-1092.

Bosnyak, S., Welungoda, I. K., Hallberg, A., Alterman, R. E., Widdop, M., and Jones, E. S. (2010). Stimulation of angiotensin AT2 receptors by the non-peptide agonist, Compound 21, evokes vasodepressor effects in conscious spontaneously hypertensive rats. Br. J. Pharmacol. 159, 709-716.

Bottari, S. P., Obermuller, N., Bogdal, Y., Zahs, K. R., and Deschepper, C. F. (1992). Characterization and distribution of angiotensin II binding sites in fetal and neonatal astrocytes from different rat brain regions. Brain Res. 585, 372-376.

Buee, L., Bussiere, T., Buee-Scherrer, V., Delacourte, A., and Hof, P. R. (2000). Tau protein isoforms, phosphorylation and role in neurodegenerative disorders. Brain Res. Brain Res. Rev. 33, 95-130.

Buisson, B., Laflamme, L., Bottari, S. P., De Gasparo, M., Gallo-Payet, N., and Payet, M.-D. (1995). A G protein is involved in the angiotensin AT2 receptor inhibition of the T-type calcium current in non-differentiated NG 108-15 cells. J. Biol. Chem. 270, 1670-1674.

Côté, F., Do, T., Laflamme, L., Gallo, J., and Gallo-Payet, N. (1999). Activation of the AT2 receptor of angiotensin II induces neurite outgrowth and cell migration in microexplant cultures of the cerebellum. J. Biol. Chem. 274, 31686-31692.

Craft, S. (2006). Insulin resistance syndrome and Alzheimer disease: pathophysiologic mechanisms and therapeutic implications. Alzheimer Dis. Assoc. Disord. 20, 298-301.

Craft, S. (2009). The role of metabolic disorders in Alzheimer disease and vascular dementia: two roads converged. Arch. Neurol. 66, 300-305.

Cui, T., Nakagami, H., Iwai, M., Takeda, Y., Shiuchi, T., Daviet, L., Nahmias, C., and Horiuchi, M. (2001). Pivotal role of tyrosine phosphatase SHP-1 in AT2 receptor-mediated apoptosis in rat fetal vascular smooth muscle cell. Cardiovasc. Res. 49, 863-871.

de Gasparo, M., Catt, K. J., Inagami, T., Wright, J. W., and Unger, T. (2000). International union of pharmacology. XXIII. The angiotensin II receptors. Pharmacol. Rev. 52, 415-472.

de Kloet, A. D., Krause, E. G., and Woods, S. C. (2010). The renin angiotensin system and the metabolic syndrome. Physiol. Behav. 100, 525-534. de la Monte, S. M. (2009). Insulin resistance and Alzheimer's disease. BMB Rep. 42, 475-481.

de la Torre, J. C. (2004). Is Alzheimer's disease a neurodegenerative or a vascular disorder? Data, dogma, and dialectics. Lancet Neurol. 3, 184-190.

Dubey, R. K., Flammer, J., and Luscher, T. F. (1998). Angiotensin II and insulin induce growth of ciliary artery smooth muscle: effects of AT1/AT2 antagonists. Invest. Ophthalmol. Vis. Sci. 39, 2067-2075.

Fabiani, M. E., Sourial, M., Thomas, W. G., Johnston, C. I., and Frauman, A. G. (2001). Angiotensin II enhances noradrenaline release from sympathetic nerves of the rat prostate via a novel angiotensin receptor: implications for the pathophysiology of benign prostatic hyperplasia. J. Endocrinol. 171, 97-108.

Farkas, E., and Luiten, P. G. (2001). Cerebral microvascular pathology in aging and Alzheimer's disease. Prog. Neurobiol. 64, 575-611.

Feng, Y. H., Sun, Y., and Douglas, J. G. (2002). Gbeta gamma-independent constitutive association of Galpha $s$ with SHP-1 and angiotensin II receptor AT2 is essential in AT2mediated ITIM-independent activation of SHP-1. Proc. Natl. Acad. Sci. U.S.A. 99, 12049-12054.

Ferri, C. P., Prince, M., Brayne, C., Brodaty, H., Fratiglioni, L., Ganguli, M., Hall, K., Hasegawa, K., Hendrie, H., Huang, Y., Jorm, A., Mathers, C., Menezes, P. R., Rimmer, E., and Scazufca, M. (2005). Global prevalence of dementia: a Delphi consensus study. Lancet 366, 2112-2117.

Fujita, T., Mogi, M., Min, L. J., Iwanami, J., Tsukuda, K., Sakata, A., Okayama, H., Iwai, M., Nahmias, C., Higaki, J., and Horiuchi, M. (2009). Attenuation of cuff-induced neointimal formation by overexpression of angiotensin II type 2 receptorinteracting protein 1. Hypertension 53, 688-693.

Funke-Kaiser, H., Reinemund, J., Steckelings, U. M., and Unger, T. (2010). Adapter proteins and promoter regulation of the angiotensin II type 2 receptor - implications for cardiac pathophysiology. J. Renin Angiotensin Aldosterone Syst. 11, 7-17.

Gallinat, S., Yu, M., Dorst, A., Unger, T., and Herdegen, T. (1998). Sciatic nerve transection evokes lasting up-regulation of angiotensin AT2 and AT1 receptor mRNA in adult rat dorsal root ganglia and sciatic nerves. Brain Res. Mol. Brain Res. 57, 111-122.

Gallo, J. M., Noble, W., and RodriguezMartin, T. R. (2007). RNA and protein-dependent mechanisms in tauopathies: consequences for therapeutic strategies. Cell. Mol. Life Sci. 64, 1701-1714.

Gao, L., Wang, W., Li, H., Sumners, C., and Zucker, I. H. (2008). Effects of angiotensin type 2 receptor overexpression in the rostral ventrolateral medulla on blood pressure and urine excretion in normal rats. Hypertension 51, 521-527.

Gelosa, P., Pignieri, A., Fändriks, L. de Gasparo, M., Hallberg, A., Banfi, C., Castiglioni, L., Turolo, L., Guerrini, U., Tremoli, E., and Sironi, L. (2009). Stimulation of AT2 receptor exerts beneficial effects in strokeprone rats: focus on renal damage. $J$. Hypertens. 27, 2444-2451.

Gendron, L., Oligny, J. F., Payet, M. D., and Gallo-Payet, N. (2003a). Cyclic AMP-independent involvement of Rap1/B-Raf in the angiotensin II AT2 receptor signaling pathway in NG108-15 cells. J. Biol. Chem. 278, 3606-3614.

Gendron, L., Payet, M., and Gallo-Payet, N. (2003b). The AT2 receptor of angiotensin II and neuronal differentiation: from observations to mechanisms. J. Mol. Endocrinol. 31, 359-372.

Georgsson, J., Rosenstrom, U., Wallinder, C., Beaudry, H., Plouffe, B., Lindeberg, G., Botros, M., Nyberg, F., Karlen, A., Gallo-Payet, N., and Hallberg, A. (2006). Short pseudopeptides containing turn scaffolds with high AT2 receptor affinity. Bioorg. Med. Chem. 14, 5963-5972.

Georgsson, J., Skold, C., Botros, M., Lindeberg, G., Nyberg, F., Karlen, A., Hallberg, A., and Larhed, M. (2007). Synthesis of a new class of druglike angiotensin II Cterminal mimics with affinity for the AT2 receptor. J. Med. Chem. 50, 1711-1715.

Georgsson, J., Skold, C., Plouffe, B., Lindeberg, G., Botros, M., Larhed, M., Nyberg, F., Gallo-Payet, N., Gogoll, A., Karlen, A., and Hallberg, A. (2005). Angiotensin II pseudopeptides containing 1,3,5-trisubstituted benzene scaffolds with high AT2 receptor affinity. J. Med. Chem. 48, 6620-6631.

Grammatopoulos, T. N., Jones, S. M., Ahmadi, F. A., Hoover, B. R., Snell, L. D., Skoch, J., Jhaveri, V. V., Poczobutt, A. M., Weyhenmeyer, J. A., and Zawada, W. M. (2007). Angiotensin type 1 receptor antagonist losartan, reduces MPTP-induced degeneration of dopaminergic neurons in substantia nigra. Mol. Neurodegener. 2, 1-17.

Grammatopoulos, T. N., Morris, K., Bachar, C., Moore, S., Andres, R., and Weyhenmeyer, J. A. (2004).
Angiotensin II attenuates chemical hypoxia-induced caspase- 3 activation in primary cortical neuronal cultures. Brain Res. Bull. 62, 297303.

Guimond, M. O., Roberge, C., and Gallo-Payet, N. (2010a). Fyn is involved in angiotensin II type 2 receptor-induced neurite outgrowth, but not in $\mathrm{p} 42 / \mathrm{p} 44 \mathrm{mapk}$ in NG108-15 cells. Mol. Cell. Neurosci. 45, 201-212.

Guimond, M. O., Wallinder, C., Alterman, M., Hallberg, A., and Gallo-Payet, N. (2010b). "The selective nonpeptide drug-like ligand (M24, formerly C21) as a tool to investigate the potential link between activation of the angiotensin II type-2 receptor (AT2R) and cognitive impairment," in The 7th International Congress of Neuroendocrinology, Rouen. Available at: http://icn2010.univrouen.fr/page.php?page $=$ program scientific: $\mathrm{O}-20$

Haass, C., and Selkoe, D. J. (2007). Soluble protein oligomers in neurodegeneration: lessons from the Alzheimer's amyloid beta-peptide. Nat. Rev. Mol. Cell Biol. 8, 101-112.

Hanger, D. P., Anderton, B. H., and Noble, W. (2009). Tau phosphorylation: the therapeutic challenge for neurodegenerative disease. Trends Mol. Med. 15, 112-119.

Hardy, J., and Selkoe, D. J. (2002). The amyloid hypothesis of Alzheimer's disease: progress and problems on the road to therapeutics. Science 297, 353-356.

Hein, L., Barsh, G., Pratt, R., Dzau, V., and Kobilka, B. (1995). Behavioural and cardiovascular effects of disrupting the angiotensin II type2 receptor in mice. Nature 377, 744-747.

Hernandez, F., and Avila, J. (2008). The role of glycogen synthase kinase 3 in the early stages of Alzheimer's disease. FEBS Lett. 582, 3848-3854.

Hernández, F., Gómez de Barreda, E., Fuster-Matanzo, A., Lucas, J., and Avila, J. (2010). GSK3: a possible link between beta amyloid peptide and tau protein. Exp. Neurol. 223, 322-355.

Horiuchi, M., Mogi, M., and Iwai, M. (2010). The angiotensin II type 2 receptor in the brain. J. Renin Angiotensin Aldosterone Syst. 11, 1-6.

Huang, X., Richards, E., and Sumners, C. (1996a). Mitogen-activated protein kinases in rat brain neuronal cultures are activated by angiotensin II type 1 receptors and inhibited by angiotensin II type 2 receptors. J. Biol. Chem. 271, 15635-15641. 
Huang, X. C., Sumners, C., and Richards, E. M. (1996b). Angiotensin II stimulates protein phosphatase $2 \mathrm{~A}$ activity in cultured neuronal cells via type 2 receptors in a pertussis toxin sensitive fashion. Adv. Exp. Med. Biol. 396, 209-215.

Huang, X. C., Richards, E. M., and Sumners, C. (1995). Angiotensin II type 2 receptor-mediated stimulation of protein phosphatase $2 \mathrm{~A}$ in rat hypothalamic/brainstem neuronal cocultures. J. Neurochem. 65, 2131-2137.

Iadecola, C. (2004). Neurovascular regulation in the normal brain and in Alzheimer's disease. Nat. Rev. Neurosci. 5, 347-360.

Iadecola, C., Park, L., and Capone, C. (2009). Threats to the mind: aging, amyloid, and hypertension. Stroke 40, S40-S44.

Ichiki, T., Labosky, P. A., Shiota, C., Okuyama, S., Imagawa, Y., Fogo, A., Niimura, F., Ichikawa, I., Hogan, B. L. M., and Inagami, T. (1995). Effects on blood pressure and exploratory behaviour of mice lacking angiotensin II type- 2 receptor. Nature 377, 748-750.

Iqbal, K., Liu, F., Gong, C. X., Alonso Adel, C., and GrundkeIqbal, I. (2009). Mechanisms of tauinduced neurodegeneration. Acta Neuropathol. 118, 53-69.

Iwai, M., Liu, H. W., Chen, R., Ide, A., Okamoto, S., Hata, R., Sakanaka, M., Shiuchi, T., and Horiuchi, M. (2004). Possible inhibition of focal cerebral ischemia by angiotensin II type 2 receptor stimulation. Circulation 110, 843-848.

Kang, J., Sumners, C., and Posner, P. (1992). Modulation of net outward current in cultured neurons by angiotensin II: involvement of AT1 and AT2 receptors. Brain Res. 580, 317-324.

Kang, J., Sumners, C., and Posner, P. (1993). Angiotensin II type 2 receptor-modulated changes in potassium currents in cultured neurons. Am. J. Physiol. 265, C607-C616.

Kaschina, E., Grzesiak, A., Li, J., ForystLudwig, A., Timm, M., Rompe, F., Sommerfeld, M., Kemnitz, U. R., Curato, C., Namsolleck, P., Tschope, C., Hallberg, A., Alterman, M., Hucko, T., Paetsch, I., Dietrich, T., Schnackenburg, B., Graf, K., Dahlof, B., Kintscher, U., Unger, T., and Steckelings, U. M. (2009). Angiotensin II type 2 receptor stimulation: a novel option of therapeutic interference with the renin-angiotensin system in myocardial infarction? Circulation 118, 2523-2532.
Kerr, D. S., Bevilaqua, L. R., Bonini, J. S., Rossato, J. I., Kohler, C. A., Medina, J. H., Izquierdo, I., and Cammarota, M. (2005). Angiotensin II blocks memory consolidation through an AT2 receptor-dependent mechanism. Psychopharmacology (Berl.) 179, 529-535.

Kilian, P., Campbell, S., Bilodeau, L., Guimond, M., Roberge, C., Gallo-Payet, N., and Payet, M. (2008). Angiotensin II AT2 receptor stimulation increases the rate of NG108-15 cell migration via actin depolymerization. Endocrinology 149, 2923-2933.

Klyubin, I., Wang, Q., Reed, M. N., Irving, E. A., Upton, N., Hofmeister, J., Cleary, J. P., Anwyl, R., and Rowan, M. J. (2011). Protection against Abeta-mediated rapid disruption of synaptic plasticity and memory by memantine. Neurobiol. Aging 32, 614-623.

LaFerla, F. M., Green, K. N., and Oddo, S. (2007). Intracellular amyloid-beta in Alzheimer's disease. Nat. Rev. Neurosci. 8, 499-509.

Laflamme, L., Gasparo, M., Gallo, J. M., Payet, M. D., and Gallo-Payet, N. (1996). Angiotensin II induction of neurite outgrowth by AT2 receptors in NG108-15 cells. Effect counteracted by the AT1 receptors. J. Biol. Chem. 271, 22729-22735.

Lenkei, Z., Palkovits, M., Corvol, P., and Llorens-Cortes, C. (1996). Distribution of angiotensin II type-2 receptor (AT2) mRNA expression in the adult rat brain. J. Comp. Neurol. 373, 322-339.

Lenkei, Z., Palkovits, M., Corvol, P., and Llorens-Cortes, C. (1997). Expression of angiotensin type-1 (AT1) and type-2 (AT2) receptor mRNAs in the adult rat brain: a functional neuroanatomical review. Front. Neuroendocrinol. 18:155. doi: 10.1006/frne.1997.0155

Lesne, S., Koh, M. T., Kotilinek, L., Kayed, R., Glabe, C. G., Yang, A., Gallagher, M., and Ashe, K. H. (2006). A specific amyloid-beta protein assembly in the brain impairs memory. Nature 440, 352-357.

Li, H., Gao, Y., Grobe, J. L., Raizada, M. K., Katovich, M. J., and Sumners, C. (2007a). Potentiation of the antihypertensive action of losartan by peripheral overexpression of the ANG II type 2 receptor. Am. J. Physiol. Heart Circ. Physiol. 292, H727H735.

Li, J. M., Mogi, M., Tsukuda, K., Tomochika, H., Iwanami, J., Min, L. J., Nahmias, C., Iwai, M., and Horiuchi, M. (2007b). Angiotensin II-induced neural differentiation via angiotensin II type 2
(AT2) receptor-MMS2 cascade involving interaction between AT2 receptor-interacting protein and Src homology 2 domain-containing protein-tyrosine phosphatase 1 . Mol. Endocrinol. 21, 499-511.

Li, J., Culman, J., Hortnagl, H., Zhao, Y., Gerova, N., Timm, M., Blume, A., Zimmermann, M., Seidel, K., Dirnagl, U., and Unger, T. (2005). Angiotensin AT2 receptor protects against cerebral ischemiainduced neuronal injury. FASEB $J$. 19, 617-619.

Lithell, H., Hansson, L., Skoog, I., Elmfeldt, D., Hofman, A., Olofsson, B., Trenkwalder, P., and Zanchetti, A. (2003). The Study on Cognition and Prognosis in the Elderly (SCOPE): principal results of a randomized double-blind intervention trial. J. Hypertens. 21, 875-886.

Liu, R., Gao, M., Qiang, G. F., Zhang, T. T., Lan, X., Ying, J., and Du, G. H. (2009). The anti-amnesic effects of luteolin against amyloid beta(25-35) peptide-induced toxicity in mice involve the protection of neurovascular unit. Neuroscience 162, 1232-1243.

Lucius, R., Gallinat, S., Rosenstiel, P., Herdegen, T., Sievers, J., and Unger, T. (1998). The angiotensin II type 2 (AT2) receptor promotes axonal regeneration in the optic nerve of adult rats. J. Exp. Med. 188, 661-670.

Martineau, D., Lamouche, S., Briand, R., and Yamaguchi, N. (1999). Functional involvement of angiotensin AT2 receptor in adrenal catecholamine secretion in vivo. Can. J. Physiol. Pharmacol. 77, 367-374.

Maul, B., von Bohlen Und Halbach, O., Becker, A., Sterner-Kock, A., Voigt, J. P., Siems, W. E., Grecksch, G., and Walther, T. (2008). Impaired spatial memory and altered dendritic spine morphology in angiotensin II type 2 receptor-deficient mice. J. Mol. Med. 86, 563-571.

McCarthy, C. A., Vinh, A., Callaway, J. K., and Widdop, R. E. (2009). Angiotensin AT2 receptor stimulation causes neuroprotection in a conscious rat model of stroke. Stroke 40, 1482-1489.

Meffert, S., Stoll, M., Steckelings, U. M., Bottari, S. P., and Unger, T. (1996). The angiotensin II AT2 receptor inhibits proliferation and promotes differentiation in PC12W cells. Mol. Cell. Endocrinol. 122, 59-67.

Mendelsohn, F. A., Allen, A. M., Clevers, J., Denton, D. A., Tarjan, E., and McKinley, M. J. (1988). Localization of angiotensin II receptor binding in rabbit brain by in vitro autoradiography. J. Comp. Neurol. 270, 372-384.
Millan, M. A., Jacobowitz, D. M., Aguilera, G., and Catt, K. J. (1991). Differential distribution of AT1 and AT2 angiotensin II receptor subtypes in the rat brain during development. Proc. Natl. Acad. Sci. U.S.A. 88, 11440-11444.

Mogi, M., and Horiuchi, M. (2009). Effects of angiotensin II receptor blockers on dementia. Hypertens. Res. 32, 738-740.

Mogi, M., Iwai, M., and Horiuchi, M. (2007a). Emerging concepts of regulation of angiotensin II receptors: new players and targets for traditional receptors. Arterioscler. Thromb. Vasc. Biol. 27 2532-2539.

Mogi, M., Tsukuda, K., Li, J. M., Iwanami, J., Min, L. J., Sakata, A., Fujita, T., Iwai, M., and Horiuchi, M. (2007b). Inhibition of cognitive decline in mice fed a high-salt and cholesterol diet by the angiotensin receptor blocker, olmesartan. $\mathrm{Neu}$ ropharmacology 53, 899-905.

Mogi, M., Li, J. M., Iwanami, J., Min, L. J., Tsukuda, K., Iwai, M., and Horiuchi, M. (2006). Angiotensin II type-2 receptor stimulation prevents neural damage by transcriptional activation of methyl methanesulfonate sensitive 2. Hypertension 48, 141-148.

Mogi, M., Li, J. M., Tsukuda, K., Iwanami, J., Min, L. J., Sakata, A., Fujita, T., Iwai, M., and Horiuchi, M. (2008). Telmisartan prevented cognitive decline partly due to PPARgamma activation. Biochem. Biophys. Res. Commun. 375, 446-449.

Mucke, L. (2009). Neuroscience: Alzheimer's disease. Nature 461, 895-897.

Mucke, L., Masliah, E., Yu, G. Q., Mallory, M., Rockenstein, E. M., Tatsuno, G., Hu, K., Kholodenko, D., Johnson-Wood, K., and McConlogue, L. (2000). High-level neuronal expression of abeta 1-42 in wild-type human amyloid protein precursor transgenic mice: synaptotoxicity without plaque formation. J. Neurosci. 20, 4050-4058.

Murugaiah, A. M., Wallinder, C., Mahalingam, A. K., Wu, X., Wan, Y., Plouffe, B., Botros, M., Karlen, A., Hallberg, M., Gallo-Payet, N., and Alterman, M. (2007). Selective angiotensin II AT(2) receptor agonists devoid of the imidazole ring system. Bioorg. Med. Chem. 15, 7166-7183.

Nelson, P. T., Braak, H., and Markesbery, W. R. (2009). Neuropathology and cognitive impairment in Alzheimer disease: a complex but coherent relationship. J. Neuropathol. Exp. Neurol. $68,1-14$. 
Nouet, S., Amzallag, N., Li, J. M., Louis, S., Seitz, I., Cui, T. X., Alleaume, A. M., Di Benedetto, M., Boden, C., Masson, M., Strosberg, A. D., Horiuchi, M., Couraud, P. O., and Nahmias, C. (2004). Trans-inactivation of receptor tyrosine kinases by novel angiotensin II AT2 receptor-interacting protein, ATIP. J. Biol. Chem. 279, 28989-28997.

Okuyama, S., Sakagawa, T., Chaki, S., Imagawa, Y., Ichiki, T., and Inagami, T. (1999). Anxiety-like behavior in mice lacking the angiotensin II type2 receptor. Brain Res. 821, 150-159.

Phillips, M. I., and de Oliveira, E. M. (2008). Brain renin angiotensin in disease. J. Mol. Med. 86, 715-722.

Phillips, M. I., and Sumners, C. (1998). Angiotensin II in central nervous system physiology. Regul. Pept. 78, $1-11$.

Plouffe, B., Guimond, M. O., Beaudry, H., and Gallo-Payet, N. (2006). Role of tyrosine kinase receptors in angiotensin II AT2 receptor signaling: involvement in neurite outgrowth and in p42/p44mapk activation in NG108-15 cells. Endocrinology 147, 4646-4654.

Porrello, E. R., Delbridge, L. M., and Thomas, W. G. (2009). The angiotensin II type 2 (AT2) receptor: an enigmatic seven transmembrane receptor. Front. Biosci. 14, 958-972.

Qiu, C., Winblad, B., and Fratiglioni, L. (2005). The age-dependent relation of blood pressure to cognitive function and dementia. Lancet Neurol. 4, 487-499.

Reinecke, K., Lucius, R., Reinecke, A., Rickert, U., Herdegen, T., and Unger, T. (2003). Angiotensin II accelerates functional recovery in the rat sciatic nerve in vivo: role of the AT2 receptor and the transcription factor NFkappaB. FASEB J. 17, 2094-2096.

Rodrigues-Ferreira, S., and Nahmias, C. (2010). An ATIPical family of angiotensin II AT2 receptor-interacting proteins. Trends Endocrinol. Metab. 21, 684-690.

Rompe, F., Artuc, M., Hallberg, A., Alterman, M., Stroder, K., ThoneReineke, C., Reichenbach, A., Schacherl, J., Dahlof, B., Bader, M., Alenina, N., Schwaninger, M., Zuberbier, T., Funke-Kaiser, H., Schmidt, C., Schunck, W. H., Unger, T., and Steckelings, U. M. (2010). Direct angiotensin II type 2 receptor stimulation acts anti-inflammatory through epoxyeicosatrienoic acid and inhibition of nuclear factor kappaB. Hypertension 55, 924-931.

Rosenstrom, U., Skold, C., Plouffe, B., Beaudry, H., Lindeberg, G., Botros,
M., Nyberg, F., Wolf, G., Karlen, A., Gallo-Payet, N., and Hallberg, A. (2005). New selective AT2 receptor ligands encompassing a gammaturn mimetic replacing the amino acid residues 4-5 of angiotensin II act as agonists. J. Med. Chem. 48, 4009-4024.

Ruiz-Ortega, M., Lorenzo, O., Ruperez, M., Konig, S., Wittig, B., and Egido, J. (2000). Angiotensin II activates nuclear transcription factor kappaB through AT(1) and AT(2) in vascular smooth muscle cells: molecular mechanisms. Circ. Res. 86, 1266-1272.

Saavedra, J. M., Ando, H., Armando, I., Baiardi, G., Bregonzio, C., Juorio, A., and Macova, M. (2005). Anti-stress and anti-anxiety effects of centrally acting angiotensin II AT1 receptor antagonists. Regul. Pept. 128, 227-238.

Saavedra, J. M., and Benicky, J. (2007). Brain and peripheral angiotensin II play a major role in stress. Stress 10 , 185-193.

Sakata, A., Mogi, M., Iwanami, J., Tsukuda, K., Min, L. J., Fujita, T., Iwai, M., Ito, M., and Horiuchi, M. (2009). Sex-different effect of angiotensin II type 2 receptor on ischemic brain injury and cognitive function. Brain Res. 1300 , 14-23.

Schindowski, K., Belarbi, K., and Buee, L. (2008). Neurotrophic factors in Alzheimer's disease: role of axonal transport. Genes Brain Behav. 7(Suppl. 1), 43-56.

Selkoe, D. J. (2008). Soluble oligomers of the amyloid beta-protein impair synaptic plasticity and behavior. Behav. Brain Res. 192, 106-113.

Senbonmatsu, T., Saito, T., Landon, E. J., Watanabe, O., Price, E. Jr., Roberts, R. L., Imboden, H., Fitzgerald, T. G., Gaffney, F. A., and Inagami, T. (2003). A novel angiotensin II type 2 receptor signaling pathway: possible role in cardiac hypertrophy. $E M B O$ J. 22, 6471-6482.

Shibata, K., Makino, I., Shibaguchi, H., Niwa, M., Katsuragi, T., and Furukawa, T. (1997). Up-regulation of angiotensin type 2 receptor mRNA by angiotensin II in rat cortical cells. Biochem. Biophys. Res. Commun. 239, 633-337.

Song, K., Allen, A. M., Paxinos, G., and Mendelsohn, F. A. (1991). Angiotensin II receptor subtypes in rat brain. Clin. Exp. Pharmacol. Physiol. 18, 93-96.

Song, K., Allen, A. M., Paxinos, G., and Mendelsohn, F. A. (1992). Mapping of angiotensin II receptor subtype heterogeneity in rat brain. J. Comp. Neurol. 316, 467-484.
Srivareerat, M., Tran, T. T., Salim, S., Aleisa, A. M., and Alkadhi, K. A. (2011). Chronic nicotine restores normal Abeta levels and prevents short-term memory and ELTP impairment in Abeta rat model of Alzheimer's disease. Neurobiol. Aging 32, 834-844.

Steckelings, U. M., Kaschina, E., and Unger, T. (2005). The AT2 receptor-a matter of love and hate. Peptides 26, 1401-1409.

Steckelings, U. M., Rompe, F., Kaschina, E., Namsolleck, P., Grzesiak, A., Funke-Kaiser, H., Bader, M., and Unger, T. (2010a). The past, present and future of angiotensin II type 2 receptor stimulation. J. Renin Angiotensin Aldosterone Syst. 11, 67-73.

Steckelings, U. M., Larhed, M., Hallberg, A., Widdop, R. E., Jones, E. S., Wallinder, C., Namsolleck, P., Dahlof, B., and Unger, T. (2010b). Non-peptide AT2-receptor agonists. Curr. Opin. Pharmacol. 11, 1-6.

Stegbauer, J., and Coffman, T. M. (2011). New insights into angiotensin receptor actions: from blood pressure to aging. Curr. Opin. Nephrol. Hypertens. 20, 84-88.

Tajima, H., Kawasumi, M., Chiba, T., Yamada, M., Yamashita, K., Nawa, M., Kita, Y., Kouyama, K., Aiso, S., Matsuoka, M., Niikura, T., and Nishimoto, I. (2005). A humanin derivative, S14G-HN, prevents amyloid-beta-induced memory impairment in mice. J. Neurosci. Res. 79, 714-723.

Tedesco, M. A., Ratti, G., Mennella, S., Manzo, G., Grieco, M., Rainone, A. C., Iarussi, D., and Iacono, A. (1999). Comparison of losartan and hydrochlorothiazide on cognitive function and quality of life in hypertensive patients. Am. J. Hypertens. 12, 1130-1134.

Tsukuda, K., Mogi, M., Iwanami, J., Min, L. J., Sakata, A., Jing, F., Iwai, M., and Horiuchi, M. (2009). Cognitive deficit in amyloid-beta-injected mice was improved by pretreatment with a low dose of telmisartan partly because of peroxisome proliferator-activated receptorgamma activation. Hypertension 54 782-787.

Tsukuda, K., Mogi, M., Li, J. M., Iwanami, J., Min, L. J., Sakata, A., Fujita, T., Iwai, M., and Horiuchi, M. (2007). Amelioration of cognitive impairment in the type- 2 diabetic mouse by the angiotensin II type-1 receptor blocker candesartan. Hypertension 50, 1099-1105.

Tsutsumi, K., and Saavedra, J. M. (1991). Characterization and development of angiotensin II receptor subtypes
(AT1 and AT2) in rat brain. Am. J. Physiol. 261, R209-R216.

Unger, T., Badoer, E., Ganten, D., Lang, R. E., and Rettig, R. (1988). Brain angiotensin: pathways and pharmacology. Circulation 77, I40-I54.

Unger, T., and Dahlof, B. (2010). Compound 21, the first orally active, selective agonist of the angiotensin II type 2 (AT2) receptor: implications for AT2 receptor research and therapeutic potential. J. Renin Angiotensin Aldosterone Syst. 11, 75-77.

Volpe, M., Musumeci, B., De Paolis, P., Savoia, C., and Morganti, A. (2003). Angiotensin II AT2 receptor subtype: an uprising frontier in cardiovascular disease? J. Hypertens. 21, 1429-1443.

von Bohlen und Halbach, O., Walther, T., Bader, M., and Albrecht, D. (2001). Genetic deletion of angiotensin AT2 receptor leads to increased cell numbers in different brain structures of mice. Regul. Pept. 99, 209-216.

Wan, Y., Wallinder, C., Plouffe, B., Beaudry, H., Mahalingam, A. K., Wu, X., Johansson, B., Holm, M., Botoros, M., Karlen, A., Pettersson, A., Nyberg, F., Fandriks, L., Gallo-Payet, N., Hallberg, A., and Alterman, M. (2004). Design, synthesis, and biological evaluation of the first selective nonpeptide AT2 receptor agonist. J. Med. Chem. 47, 5995-6008.

Wang, J., Ho, L., Chen, L., Zhao, Z., Zhao, W., Qian, X., Humala, N., Seror, I., Bartholomew, S., Rosendorff, C., and Pasinetti, G. M. (2007). Valsartan lowers brain beta-amyloid protein levels and improves spatial learning in a mouse model of Alzheimer disease. J. Clin. Invest. 117, 3393-3402.

Whitmer, R. A., Gunderson, E. P., Barrett-Connor, E., Quesenberry, C. P. Jr., and Yaffe, K. (2005). Obesity in middle age and future risk of dementia: a 27 year longitudinal population based study. BMJ 330, 1360.

Widdop, R. E., Jones, E. S., Hannan, R. E., and Gaspari, T. A. (2003). Angiotensin AT2 receptors: cardiovascular hope or hype? $\mathrm{Br}$. J. Pharmacol. 140, 809-924.

Wray, S., and Noble, W. (2009). Linking amyloid and tau pathology in Alzheimer's disease: the role of membrane cholesterol in Abetamediated tau toxicity. J. Neurosci. 29 , 9665-9667.

Wright, J. W., Reichert, J. R., Davis, C. J., and Harding, J. W. (2002). Neural plasticity and the brain renin-angiotensin system. Neurosci. Biobehav. Rev. 26, 529-552. 
Wruck, C. J., Funke-Kaiser, H., Pufe, T., Kusserow, H., Menk, M., Schefe, J. H., Kruse, M. L., Stoll, M., and Unger, T. (2005). Regulation of transport of the angiotensin AT2 receptor by a novel membrane-associated Golgi protein. Arterioscler. Thromb. Vasc. Biol. 25, 57-64.

Wu, X., Wan, Y., Mahalingam, A. K., Murugaiah, A. M., Plouffe, B., Botros, M., Karlen, A., Hallberg, M., Gallo-Payet, N., and Alterman, M. (2006). Selective angiotensin II AT2 receptor agonists: aryl benzylimidazole structure-activity relationships. J. Med. Chem. 49, 7160-7168.

Yaffe, K., Blackwell, T., Kanaya, A. M., Davidowitz, N., Barrett-Connor, E., and Krueger, K. (2004a). Diabetes, impaired fasting glucose, and development of cognitive impairment in older women. Neurology 63, 658-663.

Yaffe, K., Kanaya, A., Lindquist, K., Simonsick, E. M., Harris, T., Shorr, R. I., Tylavsky, F. A., and Newman, A. B. (2004b). The metabolic syndrome, inflammation, and risk of cognitive decline. JAMA 292, 2237-2242.

Yamaguchi, Y., and Kawashima, S. (2001). Effects of amyloid-beta(25-35) on passive avoidance, radial-arm maze learning and choline acetyltransferase activity in the rat. Eur. J. Pharmacol. 412, 265-272.

Zhou, J., Pavel, J., Macova, M., Yu, Z. X., Imboden, H., Ge, L., Nishioku, T., Dou, J., Delgiacco, E., and Saavedra, J. M. (2006). AT1 receptor blockade regulates the local angiotensin II system in cerebral microvessels from spontaneously hypertensive rats. Stroke 37 , 1271-1276.

Zlokovic, B. V. (2005). Neurovascular mechanisms of Alzheimer's neurodegeneration. Trends Neurosci. 28, 202-208.

Zlokovic, B. V. (2008). The blood-brain barrier in health and chronic neurodegenerative disorders. Neuron 57 , 178-201.

Conflict of Interest Statement: The authors declare that the research was conducted in the absence of any commercial or financial relationships that could be construed as a potential conflict of interest.

Received: 17 May 2011; paper pending published: 16 June 2011; accepted: 20 July 2011; published online: 26 August 2011.
Citation: Gallo-Payet N, Guimond M$O$, Bilodeau L, Wallinder C, Alterman $M$ and Hallberg A (2011) Angiotensin II, a neuropeptide at the frontier between endocrinology and neuroscience: is there a link between the angiotensin II type 2 receptor and Alzheimer's disease? Front. Endocrin. 2:17. doi: 10.3389/fendo.2011.00017

This article was submitted to Frontiers in Neuroendocrine Science, a specialty of Frontiers in Endocrinology.

Copyright (c) 2011 Gallo-Payet, Guimond, Bilodeau, Wallinder, Alterman and Hallberg. This is an open-access article subject to a non-exclusive license between the authors and Frontiers Media $S A$, which permits use, distribution and reproduction in other forums, provided the original authors and source are credited and other Frontiers conditions are complied with. 